Volume 1, Number 2, 2015

\title{
Evaluation of Influence of Wall Slip on Measurement of Rheological Parameters by Means of a Hydrodynamic Measuring System
}

\author{
Hanna Krykh*, Halyna Matiko, Lyudmyla Sadovska \\ Lviv Polytechnic National University, 12, Stepan Bandera St., Lviv, 79013, Ukraine
}

Received: November 27, 2015. Revised: December 08, 2015. Accepted: December 15, 2015.

(C) 2015 The Authors. Published by Lviv Polytechnic National University.

\begin{abstract}
The technique for processing the output signals of hydrodynamic measuring system of rheological parameters of non-Newtonian fluids is presented in the paper. Hydrodynamic measuring system is built on four serially connected bridge hydrodynamic converters. The paper shows that the error of determination of rheological parameters directly from the experimental flow characteristic in consistent variables is considerable if the non-Newtonian fluid has the effect of wall slip on measuring surfaces of sensors of bridge transducers. The technique for processing the output signals of the measuring system enables to detect the wall slip and to correct the values of fluid flow-rate in each bridge hydrodynamic converter using the values of the wall slip coefficient. Corrected flow characteristic is the basis for the determination of rheological parameters of controlled fluid. The influence of wall slip on the evaluation of rheological model of non-Newtonian fluid and results of measurement of its parameters are analyzed in the paper. It is shown that taking into account the effect of wall slip significantly improves measuring accuracy of rheological parameters.
\end{abstract}

Keywords: hydrodynamic measuring system; bridge hydrodynamic transducer; non-Newtonian fluid; rheological parameters; wall slip.

\section{Definition of the problem to be solved}

The systems for measuring and automatic control of quality characteristics of media particularly physical and mechanical parameters of fluids are widely used in the control systems of various technological processes. The values of these parameters during the process affect its effectiveness and the quality of the final product. Many industrial processes use non-Newtonian fluids. Ordinary design of viscometer (capillary, rotational, vibrational) provide high accuracy of measurement of viscosity of Newtonian fluids. The application of these devices for measuring rheological parameters of non-Newtonian fluids requires the analysis of additional methodical errors arising from the special properties of these fluids $[1,2]$. Particularly, during the movement of some non-Newtonian fluids especially disperse and multiphase fluids the slip effect appears at the solid surfaces of viscometer. It is called wall slip effect $[3,4]$. If these features of motion of non-Newtonian fluids are neglected, significant methodical errors of measurement of rheological parameters will occur.

\section{Analysis of the recent publications and research works on the problem}

The known methods for reducing the methodical error of measurement of rheological parameters caused by wall slip are considered below. There are several hypothesis of wall slip appearance [2-4]. One of them is that during the fluid movement in the measuring tube, a thin layer of fluid with viscosity lower than the inside flow viscosity is formed at the wall-fluid interface. This phenomenon leads to increasing of flow rate through the measuring tube.

${ }^{*}$ Corresponding author. Email address: gannakrih@gmail.com 
The universal equation for non-Newtonian fluids with different rheological behavior is used to obtain the flow rate characteristics of cylindrical tubes of round cross-section [5]

$$
\Gamma=\frac{4 F}{\pi R^{3}}=\frac{4}{\tau_{w}^{3}} \int_{0}^{\tau_{w}} \tau^{2} f(\tau) d \tau
$$

where $\tau$ is a shear stress; $\tau_{w}$ is a wall shear stress; $R$ is the radius of tube; $\Gamma$ is an apparent wall shear rate; $F$ is a volumetric flow rate in the tube; $\dot{\gamma}=f(\tau)$ is the rheological model of non-Newtonian fluid that establishes a relation between the shear rate $\dot{\gamma}$ and shear stress. One of the assumptions during its evaluation is that there is no "slip" of fluid on the tube surface, i.e. the velocity of fluid at the wall-fluid interface is assumed to be zero.

It was shown in the papers [3, 4] that changes in flow rate caused by the slip effect are almost completely determined by the velocity in the wall layer. Based on this the artificial way of processing of the experimental data obtained at studying, the fluids movement in tubes of different diameters was proposed. This method provides spreading the friction law on the near-wall layer and setting velocity $u_{s}$ at the wall which is different from zero. It changes boundary conditions in the solution of the universal equation of fluid motion. In this case the expression for the apparent shear rate on the wall of the circular tube has the form

$$
\Gamma_{m}=\frac{4 u_{s}}{R}+\frac{4}{\tau_{w}^{3}} \int_{0}^{\tau_{w}} \tau^{2} f(\tau) d \tau
$$

where $\Gamma_{m}$ is the apparent wall shear rate which is determined by experimental flow rate; $\frac{u_{s}}{R}$ is the correction on the wall slip. So we consider that due to the wall slip the flow rate $F$ in the measuring tube increases by some value $F_{s}=\pi R^{2} u_{s}$ and the apparent shear rate equals

$$
\Gamma_{m}=\Gamma+\frac{4 u_{s}}{R}
$$

The formula (2) shows that the expression $\frac{1}{\tau_{w}{ }^{3}} \int_{0}^{\tau_{w}} \tau^{2} f(\tau) d \tau$ does not depend on the radius $R$ of the tube. Therefore, if the experimental point does not lay on a curve on the graph in the coordinates $\Gamma$ and $\tau_{w}$, it means that $\frac{u_{s}}{R}$ is not equal to zero and there is the wall slip effect.

In practice of rheology studies $[3,5]$ the slip coefficient is determined by the formula

$$
s=\frac{u_{s}}{\tau_{w}}
$$

Experimental and theoretical investigations proved [2,3] that the slip coefficient $s$ is a function of shear stress on the wall and also inversely depends on the radius of the tube. Taking into account this relation and also the formula (4), the equation (3) is represented as

$$
\frac{\Gamma_{m}}{4 \tau_{w}}=\frac{\Gamma}{4 \tau_{w}}+\frac{s}{R}
$$

More detailed studies [6,7] showed that the relation between complex $\frac{\Gamma_{m}}{4 \tau_{w}}$ and $\frac{1}{R}$ is nonlinear for many nonNewtonian fluids. If the slip coefficient $s$ is corrected by the formula $s=\frac{s_{c}}{R}$, the equation (5) takes the form 


$$
\frac{\Gamma_{m}}{4 \tau_{w}}=\frac{\Gamma}{4 \tau_{w}}+\frac{s_{c}}{R^{2}}
$$

and the relation between $\frac{\Gamma_{m}}{4 \tau_{w}}$ and $\frac{1}{R^{2}}$ for all values of wall shear stress is approximately linear. Equation (6) is the basic equation for evaluation of the corrected slip coefficient $s_{c}$. It can be found from the measurements on tubes at least with three different diameters. According to the relation $\frac{\Gamma_{m}}{4 \tau_{w}}$ from $\tau_{w}$ for the different values of the tube radius we determine the relation between $\frac{\Gamma_{m}}{4 \tau_{w}}$ and $\frac{1}{R^{2}}$ at the constant values $\tau_{w}$ and then - the value of corrected slip coefficient $s_{c}$ for each value $\tau_{w}$. The result is the relation of the slip coefficient $s_{c}$ versus the wall shear stress $\tau_{w}$. This relation is accepted to be linear with sufficient accuracy for practical measurement

$$
S_{c}=a_{1} \tau_{w}+a_{0} .
$$

Found coefficient $s_{c}$ is used to correct the measured apparent shear rate $\Gamma_{m}$

$$
\Gamma=\Gamma_{m}-\frac{4 s_{c} \tau_{w}}{R^{2}}
$$

Processing of experimental data by means of the presented technique will decrease the influence of wall slip on the results of determination of rheological parameters of non-Newtonian fluids.

\section{Formulation of the goal of the paper}

The goal of the research is to improve the accuracy of measurement of the rheological parameters of non-Newtonian fluids by means of hydrodynamic measurement system by reducing of the methodical errors caused by the wall slip.

\section{Presentation and discussion of the research results}

The hydrodynamic measuring system (HDMS) is intended for measuring the rheological parameters of nonNewtonian fluid in a wide range of shear rates $[8,9]$. It consists of the series-connected bridge hydrodynamic measuring transducers (BHDT) which operate in a mode of constant fluid flow rate [8]. Each BHDT contains the tubes with the same diameter which are connected in a hydraulic bridge scheme. Opposite shoulders of BHDT have the tubes with the same length. The adjacent shoulders have the tubes of different lengths. Bridge scheme of connection of the tubes at BHDT provides compensation one of the methodical errors of measurement - the entrance effects of the tubes [8,9]. Figure 1 shows that the output signal of BHDT is a differential pressure in the measuring diagonal.

Fig. 1. The scheme of BHDT:

1,4 - short tubes with the length $L_{\mathrm{s}} ; 2,4$ - long tubes with the length $L_{i} ; 5$ - differential pressure transducer; 6 - sections between tubes; 7,8 - inlet and outlet sections; 9 - setting device of flow rate

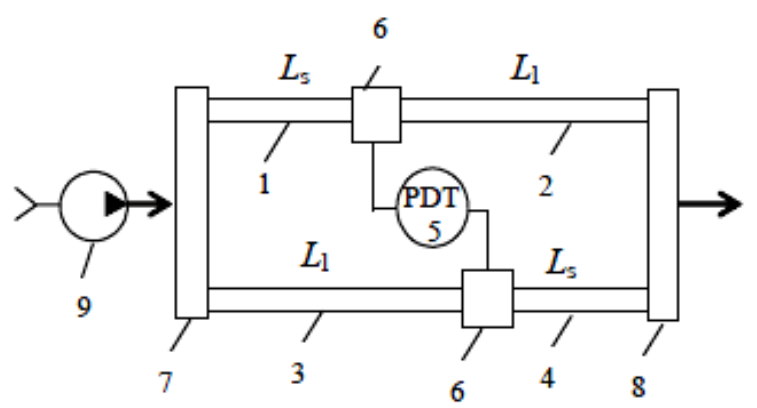

Hydrodynamic measurement transducer of rheological parameters has several BHDT which has different diameters and lengths of tubes. The diameter and the lengths of the tubes in each BHDT depend on the measuring range of rheological parameters as well as required range of shear rates and shear stresses. The length of all tubes in each BHDT exceeds the entrance length. 
The number of BHDT in hydrodynamic transducer depends on the rheological model of controlled fluid as well as the requirements for the accuracy of measurement of its rheological parameters. HDMS contains the frequency converter to control the asynchronous motor of the setting device of fluid flow. It is used to provide laminar flow regime in the tubes of all BHDT and to change the flow rate during the analysis of wall slip.

In order to measure the rheological parameters of raw oil, we used the HDMS built on the basis of four BHDT. Constructive and regime characteristics of the BHDTs are given in Table 1.

Table 1. Constructive characteristics of BHDT

\begin{tabular}{|l|c|c|c|c|}
\hline Number of bridge transducer & 1 & 2 & 3 & 4 \\
\hline Diameter of tubes, $\mathrm{mm}$ & 4.000 & 5.000 & 6.002 & 7.990 \\
\hline Difference between lengths of tubes $\Delta L, \mathrm{~m}$ & 0.20 & 0.25 & 0.30 & 0.40 \\
\hline
\end{tabular}

We selected following rheological models as the basic models to describe the flow of non-Newtonian fluid:

Ostwald power law model: $\tau=K \cdot \dot{\gamma}^{n}$,

Bingham model: $\tau=\tau_{0}+\eta \cdot \dot{\gamma}$,

Gerschel-Bulkley model: $\tau=\tau_{0}+K \cdot \dot{\gamma}^{n}$,

where $K, n$ are consistency index and nonlinearity index; $\eta$ is plastic viscosity; $\tau_{0}$ is yield stress. The equations of flow rate characteristics in consistent variables of hydrodynamic bridge transducers [10] are obtained for each of these models based on the relationship (1)

for power law model

$$
\Gamma=\frac{4 n}{3 n+1} \cdot\left(\frac{\tau_{w}}{K}\right)^{1 / n}
$$

for Bingham model

$$
\Gamma=\frac{\tau_{w}}{\eta} \cdot\left[1-\frac{4}{3} \cdot \frac{\tau_{0}}{\tau_{w}}+\frac{1}{3} \cdot\left(\frac{\tau_{0}}{\tau_{w}}\right)^{4}\right]
$$

and for Gerschel-Bulkley model

$$
\Gamma=\frac{4 n}{3 n+1} \cdot\left(\frac{\tau_{w}}{K} \cdot\left(1-\frac{\tau_{0}}{\tau_{w}}\right)\right)^{\frac{1}{n}} \cdot\left[1-\frac{1}{2 n+1} \cdot \frac{\tau_{0}}{\tau_{w}} \cdot\left(1+\frac{2 n}{n+1} \cdot \frac{\tau_{0}}{\tau_{w}} \cdot\left(1+\frac{n \tau_{0}}{\tau_{w}}\right)\right)\right]
$$

where $\tau_{w}=\frac{\Delta p R}{2 \Delta L}$ is the shear stress on the inner wall of BHDT tubes; $R$ is the inner radius of BHDT tubes; $\Delta L=L_{l}-L_{s}$ is the difference between the long length and the short length of BHDT tubes; $\Delta p$ is the differential pressure at the output diagonal of BHDT.

The optimization method of Nelder-Mead is used to determine the rheological parameters. The root mean square deviation $\sigma_{\Gamma}$ of calculated values of apparent shear rate in bridge transducers from the experimental values is chosen as an optimality criterion $[8,11,12]$

$$
\sigma_{\Gamma}=\sqrt{\frac{1}{N} \sum_{i=1}^{N}\left(\Gamma_{i}^{c}-\Gamma_{i}\right)^{2}}
$$

where $\Gamma_{i}^{c}, \Gamma_{i}$ are calculated by selected rheological model and experimental values of apparent wall shear rate; $N=4$ is the number of BHDT in the measuring system. 
The values of differential pressure in sections between tubes for each BHDT (see. Table. 2) obtained at two different values of fluid flow through MHDP $100 \mathrm{l} / \mathrm{h}$ and $75 \mathrm{l} / \mathrm{h}$ were measured to evaluate the wall slip and its influence on the rheological parameters of the controlled fluid.

According to the presented technique of processing of experimental data first we built the curve of values $\frac{\Gamma_{m}}{4 \tau_{w}}$ versus shear stress $\tau_{w}$ calculated by the measured flow rate and differential pressure at all BHDT.

Table 2. The input data for determination the rheological parameters

\begin{tabular}{|c|c|c|}
\hline \multirow{2}{*}{$\begin{array}{c}|c| \\
\text { Number of bridge transducer }\end{array}$} & 100 & 75 \\
\cline { 2 - 3 } & 12.95 & 10.46 \\
\hline 1 & 7.70 & 6.33 \\
\hline 2 & 5.30 & 4.25 \\
\hline 3 & 2.90 & 2.34 \\
\hline 4 & & \\
\hline
\end{tabular}

Fig. 2 shows that for every BHDT, i.e. for each diameter of tubes, two pairs of values $\frac{\Gamma_{m}}{4 \tau_{w}}$ and $\tau_{w}$ were obtained. Then we approximated the value of consistent variables by a power law equation for each value of $R$ (approximated values are shown by solid lines at Fig. 2) and estimated the curve of $\frac{\Gamma_{m}}{4 \tau_{w}}$ versus $\tau_{w}$ within the investigated interval of shear stress.

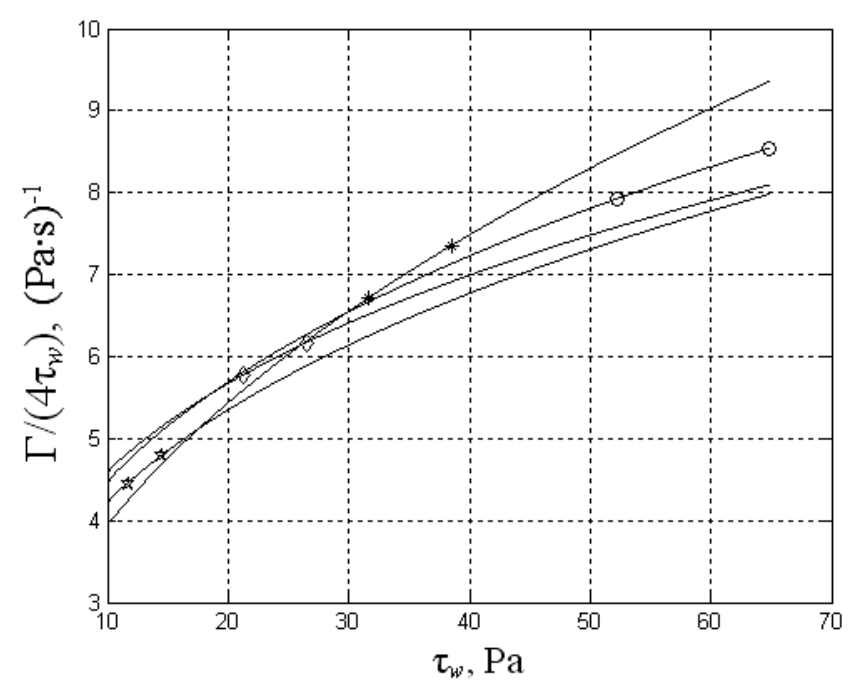

Fig. 2. The curve of $\Gamma /\left(4 \tau_{w}\right)$ versus $\tau_{w}$ : $\mathrm{o}-R_{1} ; *-\mathrm{R}_{2} ; \diamond-R_{3} ;$ म $-R_{4}$

Then, we found the values of the complex $\frac{\Gamma_{m}}{4 \tau_{w}}$ corresponding to four different values $\tau_{w}$ (minimum, maximum and two intermediate values), for example $\tau_{w}=\left[\begin{array}{llll}65 & 45 & 30 & 10\end{array}\right]$ using four obtained equations. They were approximated by linear equations for each selected value $\tau_{w}$

$$
\frac{\Gamma_{m}}{4 \tau_{w}}=a \frac{1}{R^{2}}+b .
$$

The results of approximation are shown in Fig. 3. 


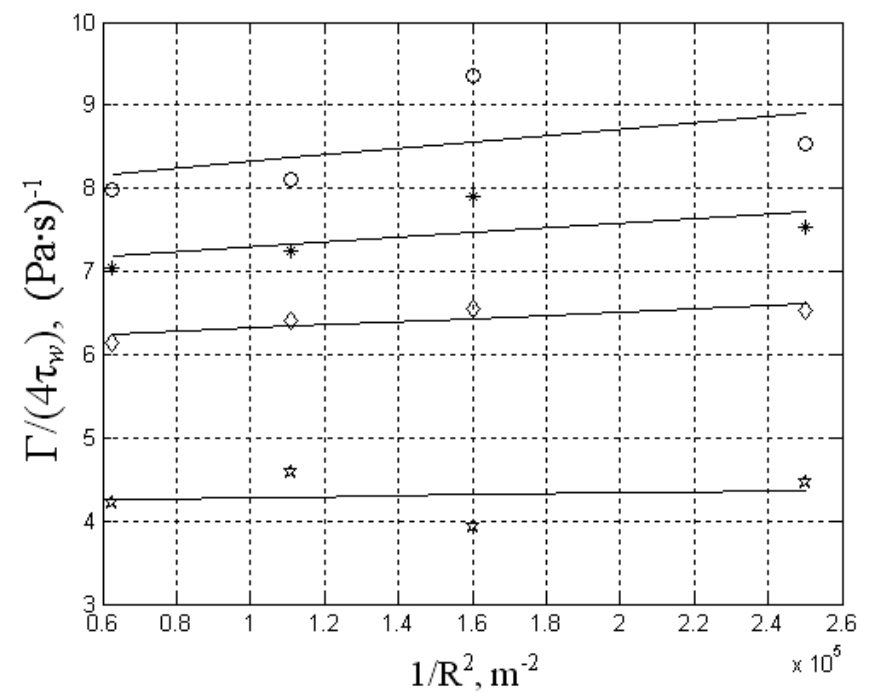

Fig. 3. The results of approximation of the values $\Gamma /\left(4 \tau_{\mathrm{w}}\right)$ versus $1 / R^{2}$ for different values $\tau_{w}$ : 'o' $-65 \mathrm{~Pa}$; ‘*' $-45 \mathrm{~Pa}$; ‘仓' $-30 \mathrm{~Pa}$; ‘出' $-10 \mathrm{~Pa}$

Calculated coefficients $a$ i $b$ of linear equation (16) are shown in Table 3.

Table 3. The coefficient of approximating equation (16) for different values of shear stress

\begin{tabular}{|c|c|c|}
\hline$\tau_{w}, \mathrm{~Pa}$ & $a$ & $b$ \\
\hline 65 & $0.4542136429 \mathrm{e}-5$ & 8.278287668 \\
\hline 45 & $0.3015703133 \mathrm{e}-5$ & 7.170699622 \\
\hline 30 & $0.1774653768 \mathrm{e}-5$ & 6.138890036 \\
\hline 10 & $0.0075184886 \mathrm{e}-5$ & 4.085429662 \\
\hline
\end{tabular}

Each coefficient $a$ is the value of the slip coefficient $s_{c}$ at the certain value of the shear stress $\tau_{w}$. We approximated coefficients $a$ from $\tau_{w}$ by the linear equation (7) and got the following value of coefficients $a_{l}=0.60872514 \mathrm{e}-7, a_{0}=0.15088735 \mathrm{e}-7$.

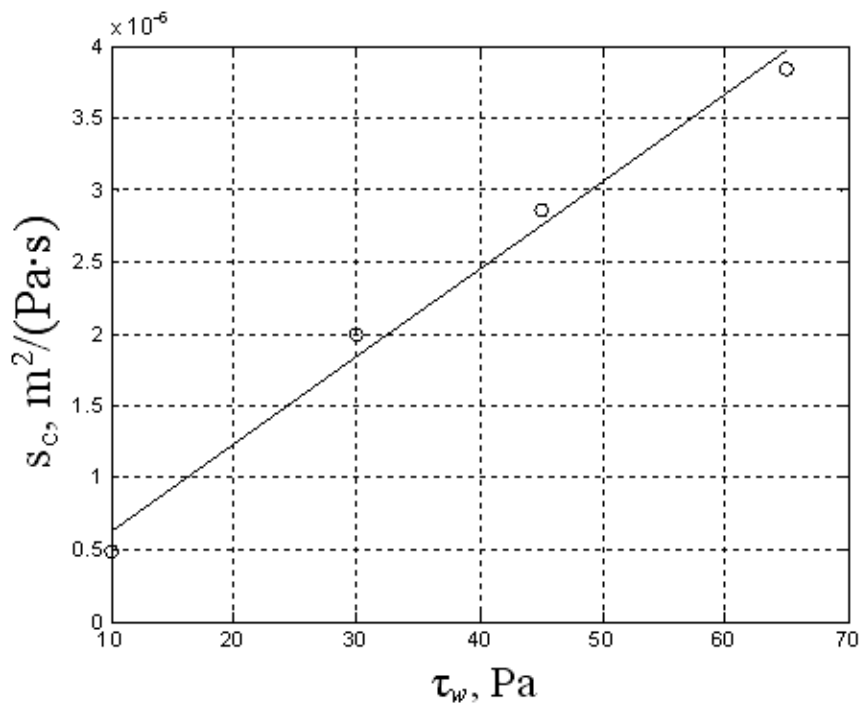

Fig. 4. The curve of slip coefficient $s_{c}$ versus shear stress $\tau_{w}$ 
Then we corrected the value of apparent shear rate $\Gamma_{m}=\left[\begin{array}{llllll}2210.49 & 1131.77654 .30 & 277.35\end{array}\right]$ for each bridge hydrodynamic transducer by formula (8) using the slip coefficient $s_{c}$ and obtained the corrected values of apparent shear rate $\Gamma=\left[\begin{array}{lll}1954.30 & 1073.65 & 635.13274 .10\end{array}\right]$ at BHDT respectively with the radius of tubes $R=2 \mathrm{~mm}, 2.5 \mathrm{~mm}$, $3.001 \mathrm{~mm}$ and $3.995 \mathrm{~mm}$. Fig. 5 shows the experimental flow rate characteristic in consistent variables for $F_{m}=100 \mathrm{l} / \mathrm{h}$ and the corrected flow rate characteristic.

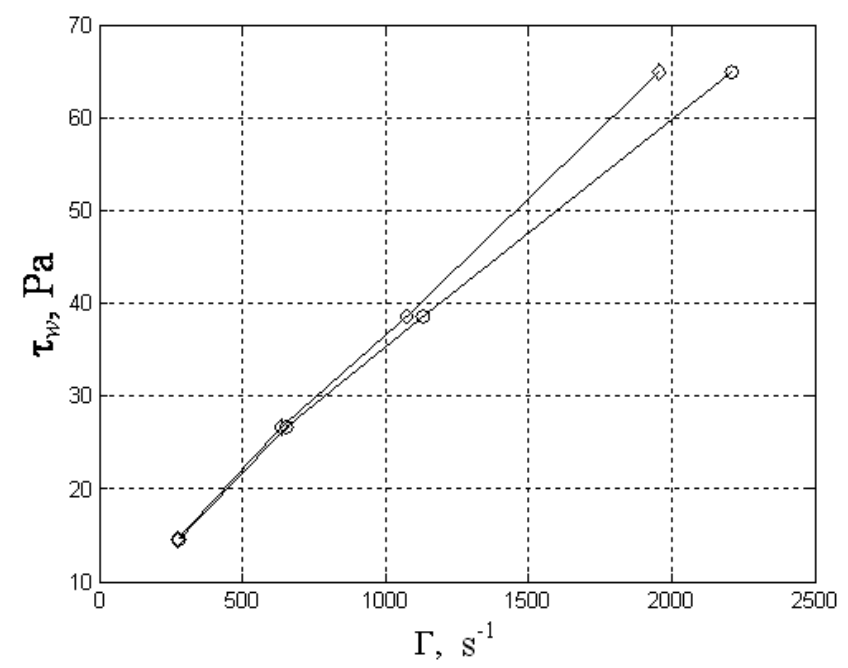

Fig. 5. The curve of wall shear stress $\tau_{w}$ versus apparent wall shear rate $\Gamma$ : 'o' - without wall slip; ' $\diamond$ ' - with wall slip

We calculated the rheological parameters for selected rheological models (power law, Bingham, GerschelBulkley) taking into account the values of apparent wall shear rate corrected by the wall slip. The results of calculation are presented in Table 4.

Table 4. The values of rheological parameters for different rheological models calculated using experimental data and the data corrected by the wall slip

\begin{tabular}{|c|c|c|c|c|c|c|c|c|c|c|}
\hline \multirow{3}{*}{$\begin{array}{l}\text { Apparent } \\
\text { shear rate }\end{array}$} & \multicolumn{10}{|c|}{ Rheological model } \\
\hline & \multicolumn{3}{|c|}{ Ostwald } & \multicolumn{3}{|c|}{ Bingham } & \multicolumn{4}{|c|}{ Gerschel-Bulkley } \\
\hline & $K, \mathrm{~Pa} \cdot \mathrm{s}^{\mathrm{n}}$ & $n$ & $\sigma_{\Gamma}, 1 / \mathrm{s}$ & $\eta, \mathrm{Pa} \mathrm{s}$ & $\tau_{0}, \mathrm{~Pa}$ & $\sigma_{\Gamma}, 1 / \mathrm{s}$ & $K, \mathrm{~Pa} \mathrm{~s}^{\mathrm{n}}$ & $n$ & $\tau_{0}, \mathrm{~Pa}$ & $\sigma_{\Gamma}, 1 / \mathrm{s}$ \\
\hline$\Gamma_{m}$ & 0.1973 & 0.744 & 18.96 & 0.02555 & 6.642 & 35.98 & 0.1025 & 0.8241 & 2.805 & 10.87 \\
\hline$\Gamma$ & 0.1375 & 0.8952 & 28.15 & 0.02962 & 5.199 & 16.02 & 0.0427 & 0.9527 & 4.271 & 14.00 \\
\hline
\end{tabular}

Analysis of the values of rheological parameters obtained by means of hydrodynamic measuring system shows that neglecting the effect of wall slip causes the significant measurement errors. According to the chosen criterion of adequacy, the Gerschel-Bulkley model is the best model although the simpler two-parameter model of Bingham can be used for practical application. Table 4 shows that the value of the criterion $\sigma_{\Gamma}$ for Bingham model slightly differs from the $\sigma_{\Gamma}$ for Gerschel-Bulkley model. It should be noted that the error of determination of rheological parameters $K, n$ and $\tau_{0}$ by Gerschel-Bulkley model is the largest and reaches tens of percent.

\section{Conclusion}

The technique for processing differential pressure in the output diagonals of bridge hydrodynamic transducers provides the possibility to define the rheological model of non-Newtonian fluid effectively and to improve the accuracy of measurement of the rheological parameters by reducing of methodical error caused by wall slip. According to this technique, rheological model of non-Newtonian fluid $\dot{\gamma}=f(\tau)$ and its parameters are determined directly by the flow rate characteristics of bridge hydrodynamic transducers. There is no need to determine the share rate on the wall by the Rabinowitsch-Mooney equation. The technique of correction of the flow rate characteristics of BHDT can be applied to non-Newtonian fluids with different rheological models. Correction procedure is easy 
algorithmized by existing software packages that provide high approximation accuracy with the best possible approximation to the experimental values. It is also important that the approximation of the experimental data can be made at different ranges of shear rate (by choice).

The technique for determining the wall slip coefficient by the measuring results of differential pressure in several BHDT allows correcting their flow rate characteristics and thereby improving the accuracy of determination of rheological parameters of the non-Newtonian fluids with wall slip effect.

\title{
References
}

[1] Schramm, G. A Practical Approach to Rheology and Rheometry. 2nd Edition. Gebrueder HAAKE GmbH, Karisruhe, Federal Republic of Germany. (2000).

[2] Macosko, C. W. Rheology: Principles, Measurements and Applications. VCH Publishers. New York. (1994).

[3] Mooney, M.. Explicit formulas for slip and fluidity. J Rheol 30: (1931), pp. 337-357.

[4] Oldroyd, J. G. Non-Newtonian flow of solids and liquids. In: Eirich, F. R. (editor). Rheology: Theory and Applications, Vol. 1. Academic Press Inc., New York. (1956), pp. 653-682.

[5] Steffe, J. F. Rheological Methods in Food Process Engineering, 2nd edition. Freeman Press, East Lancing, MI, USA (1996), 418 p.

[6] Jastrzebski, Z. D.. Entrance effects and wall effects in an extrusion rheometer during the flow of concentrated suspensions. Ind. Engn. Chem. Fund. 6: (1967), pp. 445-454.

[7] Shukla,A. and S.S.H.Rizvi. Measurement of flowability of butter by capillary rheometry. J Texture Stud. 26: (1995), pp. $299-311$.

[8] Y. Pistun, H. Krykh, Programmable realization of processing of the information in control systems of rheological parameters of nonNewtonian fluids, Proceedings of the National Mining University, Lviv (2011), pp. 139-147. (in Ukrainian)

[9] H. Krykh, Reducing of the errors of measurement of rheological parameters of non-Newtonian fluids by bridge hydrodynamic measuring transducers, "Methods and instruments of quality control", No. 13, Lviv (2005), pp. 87-91. (in Ukrainian)

[10] H. Krykh, Mathematical models of throttle elements for hydrodynamic measuring transducers of parameters of non-Newtonian fluids, "Heat power engineering. Environmental engineering. Automation. Proceedings of Lviv Polytechnic National University”, No. 617, Lviv (2008), pp. 122-129. (in Ukrainian)

[11] H. Krykh, Measuring of rheological parameters of power and Bingham fluids by hydrodynamic transducers, "Heat power engineering. Environmental engineering. Automation. Proceedings of Lviv Polytechnic National University”, No. 561, Lviv (2006), pp. 52-57. (in Ukrainian)

[12] H. Krykh, Determination rheological parameters of fluids by consistent variables, "Heat power engineering. Environmental engineering. Automation. Proceedings of Lviv Polytechnic National University”, No. 712, Lviv (2011), pp. 126-131. (in Ukrainian)

\section{Оцінка впливу пристінного ковзання на вимірювання реологічних параметрів гідродинамічною вимірювальною системою}

\author{
Ганна Крих, Галина Матіко, Людмила Садовська \\ Національний Університет “Львівська політехніка”, вул. С. Бандери, 12, м. Львів, 79013, Україна
}

\section{Анотація}

Розглянуто методику опрацювання вихідних сигналів гідродинамічної вимірювальної системи реологічних параметрів неньютонівських рідин. Гідродинамічна вимірювальна система побудована на базі чотирьох послідовно з'єднаних мостових гідродинамічних перетворювачів. У статті показано, що якщо неньютонівська рідина виявляс ефект пристінного ковзання на вимірювальних поверхнях чутливих елементів мостових перетворювачів, то похибки визначення реологічних параметрів безпосередньо за експериментальною витратною характеристикою у консистентних змінних будуть досить значними. Методика опрацювання вихідних сигналів вимірювальної системи дає змогу виявити наявність пристінного ковзання та скорегувати значення витрати рідини у кожному мостовому гідродинамічному перетворювачі, за допомогою знайдених значень коефіцієнта пристінного ковзання. Скорегована витратна характеристика $є$ основою для визначення реологічних параметрів контрольованої рідини. Проаналізований вплив ефекту пристінного ковзання на встановлення реологічної моделі неньютонівської рідини та результати вимірювання іiі параметрів. Показано, що врахування ефекту пристінного ковзання істотно підвищує точність вимірювання реологічних параметрів.

Ключові слова: гідродинамічна вимірювальна система; мостовий гідродинамічний перетворювач; неньютонівські рідини; реологічні параметри; пристінне ковзання. 